\title{
Desain Gerobak Pedagang Keliling pada Masa New Normal Covid-19
}

\author{
Hari Nugraha, Fitriah Nurhidayah, dan Donna Angelina \\ Desain Produk, Fakultas Teknologi dan Desain, Universitas Pembangunan Jaya, \\ Tangerang Selatan, Indonesia \\ e-mail: hari.nugraha@upj.ac.id
}

\begin{abstract}
Abstrak-Pada masa pandemi Covid-19 saat ini, pedagang keliling adalah salah satu usaha kecil yang ikut terdampak. Pendapatan mereka menurun secara drastis, salah satu penyebabnya adalah pembatasan akses masuk ke wilayah pemukiman untuk berjualan dan kepercayaan pembeli yang menurun akibat takut tertular covid-19 dari pedagang tersebut. Memasuki masa new normal, terjadi perubahan aktifitas komsumsi masyarakat dimana pedangan keliling harus dapat beradaptasi dengan perubahan pola yang terjadi. Berdasarkan kondisi tersebut, penelitian ini bertujuan untuk melakukan upgrade dan desain perangkat gerobak pedagang keliling yang dapat menyesuaikan dengan kondisi New Normal dimana ditekankan kepada desain gerobak pedagang keliling yang sesuai dengan protokol pencegahan covid-19 serta mengkondisikan berjualan dengan cara take way order. Metode yang dilakukan dalam pelaksanaan penelitian ini yaitu diawali dengan observasi lapangan, identifikasi aktifitas interaksi antara pedangan dan pembeli kemudian formulasi hasil data yang diperoleh selanjutnya menentukan spesifikasi yang diperlukan untuk proses uprade dan desain grobak. Hasil yang diperoleh yaitu desain gerobak dengani fitur yang dapat membatasi interaksi secara langsung antara penjual dan pembeli, peningkatan kebersihan melalui penyediaan perangkat sanitasi dan disinfektan yang dapat digunakan oleh pembeli, penggunaan material gerobak dari material logam dengan standar foot grade (stainless steel) dan desain dengang menerapkan prinsip ergonomi.
\end{abstract}

Kata Kunci- upgrade, pedagang keliling, pandemi, redesain, dan new normal.

Abstract-During the Covid-19 pandemic, the food vendors cart as small businesses that were affected. Their income has decreased drastically; one of the reasons is the restriction of access to residential areas to sell and the decreased trust of sellers due to the infected Covid-19 from these sellers. Entering the new normal period, there is a change in community consumption activities where the food vendors traders must adapt to changes in behavior. This study aims to upgrade and design food vendors carts that can adapt to New Normal conditions. Based on these situations, this research emphasis designing food vendors carts that implement the Covid-19 prevention protocol and changing the selling process to take way orders system. The method applied in this research is by field observations, identifying interaction activities between seller and buyers, formulating the results of the data obtained, and then determining the specifications needed for upgrading and designing the cart. The results obtained are the design of the cart with features that can make limitation interaction between the seller and the buyer, the improvement of cleanliness through the provision of sanitation and disinfectant devices that the buyer can use, changing the cart materials with food-grade metal standards (stainless steel) and the design by applying the principles of ergonomics.

Keywords-upgrade, food vendors mobile, pandemic, redesign, and new normal.

\section{PENDAHULUAN}

Pandemi Covid-19 telah berlangsung lebih dari satu tahun, sampai saat ini belum menunjukkan perbaikan kondisi, jumlah orang yang terkena dampak terus meningkat, menyebabkan perlambatan pertumbuhan perekonomian, resesi ekonomi nasional, melumpuhkan kegiatan ekonomi dan sosial [1]. Sektor Usaha Mikro, Kecil, dan Menengah (UMKM) seperti pedagang keliling yang berjualan menggunakan gerobak dorong sebagai sarana berjualan dan sifatnya mobile atau berpindah dari satu lokasi ke lokasi lainnya [2] adalah yang paling terkena dampak secara langsung karena hampir $60 \%$ berjualan di ruang publik [3].

Salah satu penyebab yang dapat diidentifikasikan dari dampak tersebut yaitu penurunan pendapatan pedagang keliling karena disebabkan beberapa faktor seperti Pemberlakukan Pembatasan Kegiatan Masyarakat (PPKM) secara luas maupun mikro yang berimbas kepada penutupan lokasi berjualan dan pembatasan akses penjual keliling untuk masuk kewilayah pemukiman penduduk. Efek lainnya yaitu kepercayaan pembeli yang menurun karena takut tertular covid-19 jika berinteraksi secara langsung dengan penjual keliling tersebut.

Setelah melewati masa gelombang pertama pandemi dan berakhirnya pembatasan aktifitas masyarakat sekala besar, pola kegiatan masyarakat diarahkan untuk dapat berjalan secara normal berdampingan dengan pandemi yang sampai saat ini belum usai. Pola kehidupan normal yang baru ini atau disebut new normal, menekankan kepada penerapan protokol masyarakat produktif dan aman dari penyebaran Covid-19 [4].

Pola kehidupan new normal dapat diterjemahkan sebagai bentuk adaptasi dari kebiasaan dalam beraktifitas dengan pola baru, artinya beraktifitas dengan menerapkan protokol kesehatan yaitu seperti memakai masker, menerapkan pola hidup bersih dan sehat [5].

Dalam melakukan aktifitas berjualan pada saat new normal ini, sebagian besar para pedagang keliling lambat beradaptasi dengan pola yang baru dan belum dapat menerapkan protokol pencegahan penyebaran Covid-19 seperti penerapan 5M (Mencuci Tangan, Memakai Masker, Menjaga Jarak, Menjauhi Kerumunan dan Mengurangi Mobilitas) [6].

Umumnya sistem berjualan yang dilakukan oleh pedagang keliling sebelum terjadinya pandemi yaitu dengan pola interaksi secara langsung antara penjual dan pembeli, cenderung untuk mengkonsumsi makanan yang dibeli dilokasi pedagang tersebut berjualan, menggunakan alat makan yang disediakan oleh penjual, area sekitar berjualan 
sebagai tempat berkumpulnya orang dan standar higienis yang kurang diperhatikan yaitu seperti dari cara penyajian makanan dan proses mencuci alat makan habis pakai yang tidak memperhatikan standar kebersihan.

Memasuki masa new normal, proses berjualan dari pedagang keliling tersebut masih menerapkan cara lama dengan standar sistem dan perlengkapan berjualan yang masih minim serta belum dapat beradaptasi dengan kondisi new normal dengan konsep 5M. Dengan kondisi seperti ini, tingkat kepercayaan pembeli akan tetap rendah dan menurunkan minat untuk membeli dagangan dari pedagang keliling tersebut.

Prinsip dasar yang dapat digunakan untuk menyesuaikan perangkat dan fasilitas pedagang keliling agar dapat berakfitas secara normal dapat merujuk kepada standar Guideline yang diterbitkan oleh Women in Informal Employment: Globalizing and Organizing (WIEGO) yaitu organisasi global dengan fokus kegiatan untuk pemberdayaan pekerja berpenghasilan rendah pada sektor ekonomi informal sebagai sumber penghasilan mereka, salah satunya yaitu seperti pedagang keliling [7]. Guideline aktivitas berjualan berdasarkan referensi dari WIEGO ditampilkan pada Tabel-tabel 1 dan 2.

\begin{tabular}{c|l}
\multicolumn{2}{c}{ Tabel 1. Guideline interaksi penjual dan pembeli berdasarkan WIEGO. } \\
\hline \hline No. & \multicolumn{1}{|c}{ Guideline interaksi antara penjual dan pembeli } \\
\hline \hline 1 & Jarak 2 meter antara gerobak penjual atau lapak penjual. \\
\hline 2 & Minimum 1 meter jarak antara pelanggan. \\
\hline 3 & $\begin{array}{l}\text { Membuat penghalang untuk membatasi interaksi antara } \\
\text { penjual dan pelanggan. }\end{array}$ \\
\hline 4 & $\begin{array}{l}\text { Menyediakan disinfektan untuk tangan yang dapat digunakan } \\
\text { oleh pelanggan. }\end{array}$ \\
\hline
\end{tabular}

Tabel 2. Guideline untuk penjual berdasarkan WIEGO

\begin{tabular}{c|l}
\hline \hline No. & \multicolumn{1}{|c}{ Guideline untuk penjual } \\
\hline \hline 1 & Hidung dan mulut tertutup masker. \\
\hline 2 & Tidak menyentuh mata, mulut dan hidung. \\
\hline 3 & Tidak bersentuhan secara langsung dengan pembeli. \\
\hline 4 & Mencuci tangan setelah melakukan aktifitas berjualan. \\
\hline 5 & $\begin{array}{l}\text { Berikan prioritas untuk pelanggan khusus seperti wanita } \\
\text { hamil dan manula. }\end{array}$ \\
\hline 6 & Meminta pembeli untuk tidak menyentuh barang yang dijual. \\
\hline 7 & $\begin{array}{l}\text { Bersihkan semua permukaan dan benda yang sering disentuh } \\
\text { menggunakan disinfektan. }\end{array}$ \\
\hline 8 & Hindari menggunakan uang tunai. \\
\hline 9 & $\begin{array}{l}\text { Hindari menggunakan kembali tas belanja dan menyentuh tas } \\
\text { belanja pembeli. }\end{array}$ \\
\hline
\end{tabular}

Sedangkan merujuk Guideline yang diterbitkan oleh U.S Food \& Drug Administration proses aktifitas berjualan new normal dapat dibagi menjadi empat aspek utama yaitu: Pengelolaan kesehatan diri penjual atau pekerja, Menjaga kebersihan individu, Pengelolaan penyajian makanan yang dijual, dan Pengaturan pengambilan dan pengantaran makanan yang dijual [8].

Beberapa cara yang sudah dilakukan dengan subjek pedagang keliling agar dapat beradaptasi dengan kondisi new normal pandemi covid-19 yaitu dengan melengkapai penjual tersebut dengan Alat Perlindungan Diri (APD). Standar APD yang umumnya digunakan untuk pencegahan penularan Covid-19 yaitu seperti masker, pelindung wajah dan sarung tangan [9].

Usaha lain yang umumnya dilakukan oleh penjual untuk melindungi diri dari penularan Covid-19 pada saat melakukan proses berjualan yaitu dengan menambahkan fitur tertentu yang dipasangkan pada gerobak penjual seperti memberi pembatas berupa tirai plastik disekeliling gerobak [10].

Penambahan fitur tirai pembatas tersebut, untuk beberapa kasus tidak dapat kompatibel dengan gerobak berjualan yang biasanya digunakan oleh penjual keliling. Tata letak dan proses penyajian serta transasksi jual beli masih menggunakan pola yang lama, sehingga penambahan tirai pembatas tersebut dapat menyulitkan penjual dalam beraktifitas.

Penggunaan plastik sebagai material pembatas harus memperhatikan tata letak peralatan yang digunakan pada gerobak yang digunakan oleh pedagang tersebut, dimana dalam pemasangannya tidak boleh berdekatan dengan kompor gas dan area memasak (suhu panas) yang ada di gerobak. Selain itu, tirai tersebut hanya efektif untuk dipasang pada bagian sisi samping dari gerobak. Dengan sistem ini, transaksi jual beli dan proses pengambilan makanan lebih difokuskan kepada pengaturan jarak interaksi antara penjual dan pembeli [10].

Selain itu, proses jual beli masih menggunakan transaksi manual (pembayarn tunai) dimana cara ini akan memperbesar kemungkinan penularan Covid-19 antara penjual dan pembeli melalui perantara uang kertas. Umumnya pedagang UMKM masih belum memahami penggunaan aplikasi transaksi digital non tunai [11] kondisi ini menyebabkan pedagang keliling belum dapat beradaptasi dengan sistem tersebut.

\begin{tabular}{c|l|l}
\multicolumn{2}{c}{ Tabel 3. Spesifikasi penyesuaian desain gerobak pedagang keliling. } \\
\hline \hline No. & \multicolumn{1}{|c}{ Eksisting Gerobak } & \multicolumn{1}{c}{ Redesain Gerobak } \\
\hline 1 & $\begin{array}{l}\text { Tidak ada pembatas interaksi } \\
\text { /pelindung jarak antara } \\
\text { pembeli dan penjual }\end{array}$ & $\begin{array}{l}\text { Fitur yang dapat membatasi } \\
\text { dan melindungi interaksi } \\
\text { antara penjual dan pembeli }\end{array}$ \\
\hline 2 & $\begin{array}{l}\text { Interaksi langsung pembeli } \\
\text { pada saat pengambilan } \\
\text { makanan }\end{array}$ & $\begin{array}{l}\text { Sistem pengambilan } \\
\text { makanan tanpa ada } \\
\text { interaksi langsung dengan } \\
\text { pembeli }\end{array}$ \\
\hline 3 & $\begin{array}{l}\text { Makan ditempat } \\
\text { menggunakan alat makan } \\
\text { dari penjual }\end{array}$ & $\begin{array}{l}\text { Sistem take way order } \\
\text { dengan kemasan sekali } \\
\text { pakai }\end{array}$ \\
\hline 4 & $\begin{array}{l}\text { Transasksi pembayaran } \\
\text { dilakukan secara tunai }\end{array}$ & $\begin{array}{l}\text { Tersedia opsi non tunai dan } \\
\text { fitur sterilisasi uang tunai }\end{array}$ \\
\hline 5 & $\begin{array}{l}\text { Menggunakan air untuk cuci } \\
\text { tangan dan membersihkan } \\
\text { area penyajian makanan }\end{array}$ & $\begin{array}{l}\text { Fitur alat disinfektan untuk } \\
\text { tangan dan membersihkan } \\
\text { area penyajian makanan }\end{array}$ \\
\hline 6 & $\begin{array}{l}\text { Tempat penyajian makanan } \\
\text { terbuat dari material kayu }\end{array}$ & $\begin{array}{l}\text { Penggunaan material } \\
\text { stainless steel food grade }\end{array}$ \\
\hline
\end{tabular}

Berdasarkan analisa situasi tahap awal yang dilakukan terhadap aktivitas penjual keliling, untuk membantu proses berjualan pada masa new normal, dapat dilakukan dengan melakukan perbaikan desain dari perangkat gerobak pedagang keliling tersebut agar sesuai dengan protokol pencegahan penyebaran covid-19. Dasar dari spesifikasi desain dapat merujuk kepada guideline WIEGO dan U.S Food \& Drug Administration, seperti dapat dilihat pada Tabel 3. Terdapat enam spesifikasi minimum yang dapat digunakan sebagai acuan melakukan perbaikan desain gerobak untuk pedagang keliling. Hasil akhir yang diharapkan, dengan melakukan perbaikan pada desain gerobak yaitu aktifitas berjualan dapat memenuhi standar kondisi new normal, pedagang keliling dapat melakukan aktifitas dengan aman, 


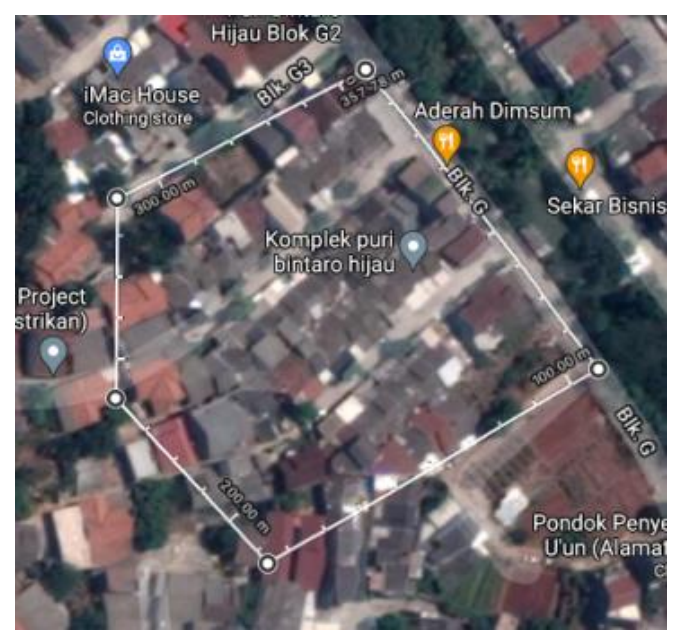

Gambar 1. Peta lokasi berjualan pedagang bakso keliling.

kepercayaan pembeli meningkat dan secara bertahap dapat memulihkan pendapatan pedagang seperti kondisi sebelum terjadinya pandemi Covid-19.

\section{METODE}

Proses desain gerobak pedagang keliling menggunakan metode descriptive observation [12], tahap awal adalah dengan melakukan pengamatan dan identifikasi proses berjualan berikut interaksi yang terjadi antara pedagang dan pembeli. Observasi yang dilakukan termasuk untuk mengamati perilaku individu (penjual dan pembeli). Selama proses observasi berlangsung, dihindari untuk tidak melakukan perubahan tertentu terhadap instrumen yang diamati. Dengan metode ini, akan didapat hasil pengamatan yang spesifik, menyediakan data secara valid berdasarkan kondisi nyata di lapangan, mendapatkan gambaran perilaku dan perubahannya secara spontan yang mungkin dapat terjadi [13].

Data yang didapat dari hasil observasi lapangan selanjutnya dianalisa dan diformulasikan sebagai dasar untuk merumuskan spesifikasi desain yang diperlukan untuk melakukan proses pembuatan desain gerobak. Selanjutnya, diwujudkan dalam bentuk rancangan objek 3 dimensi yang dibuat dengan menggunakan software pemodelan 3D.

\section{HASIL DAN PEMBAHASAN}

Penelitian ini difokuskan untuk perbaikan desain gerobak pedagang keliling dengan studi kasus yang diambil yaitu gerobak pedagang bakso yang berjualan di sekitar komplek perumahan Puri Bintaro Hijau, Tangerang Selatan Banten. Komplek perumahan ini cukup padat dan dikelilingi oleh perkampungan warga, pembeli tidak hanya dari warga komplek perumahan tetapi dari warga diluar komplek tersebut. Gambar 1 menunjukkan lokasi perumahan tempat pedagang keliling berjualan.

Jenis gerobak bakso yang digunakan untuk berjualan keliling umumya berukuran kecil dan sebagian besar terbuat dari material kayu dengan total dimensi keseluruhan yaitu panjang $110 \mathrm{~cm}$, lebar $50 \mathrm{~cm}$ dan tinggi $160 \mathrm{~cm}$. Jenis gerobak bakso yang digunakan sebagai studi kasus pada penelitian ini dapat dilihat pada Gambar 2.

Berdasarkan fungsinya gerobak yang digunakan untuk berjualan bakso keliling, dapat dibagi menjadi 4 bagian utama yaitu (a) area penyimpanan makanan, (b) persiapan dan penyajian makanan, (c) penyimpanan perlengkapan dan alat makan (d) ruang untuk penyimpanan sarana pendukung berjualan seperti tabung gas $3 \mathrm{~kg}$, kompor dan sarana untuk cuci peralatan makan (Gambar 3).

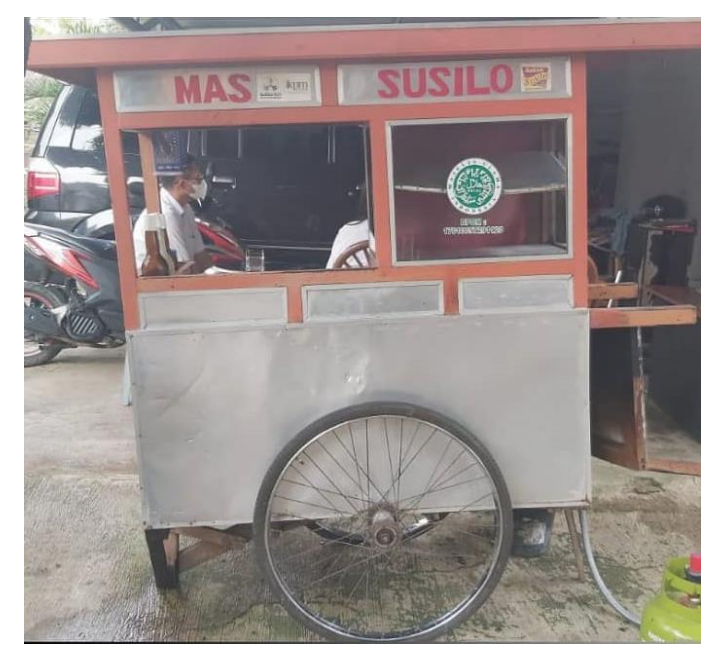

Gambar 2. Gerobak pedagang bakso keliling.

(a)

(c)

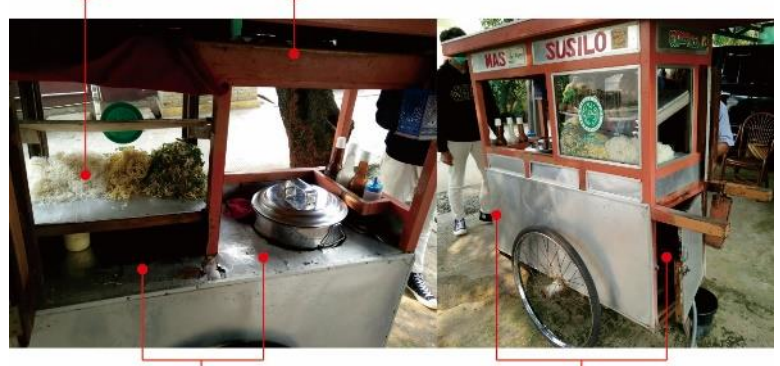

(b)

(d)

Gambar 3. Pembagian area gerobak bakso berdasarkan fungsinya (a) penyimpanan makanan, (b) penyajian makanan, (c) penyimpanan perlengkapan makan (d) ruang penyimpanan tabung gas, kompor dan perlengkapam untuk cuci peralatan makan.

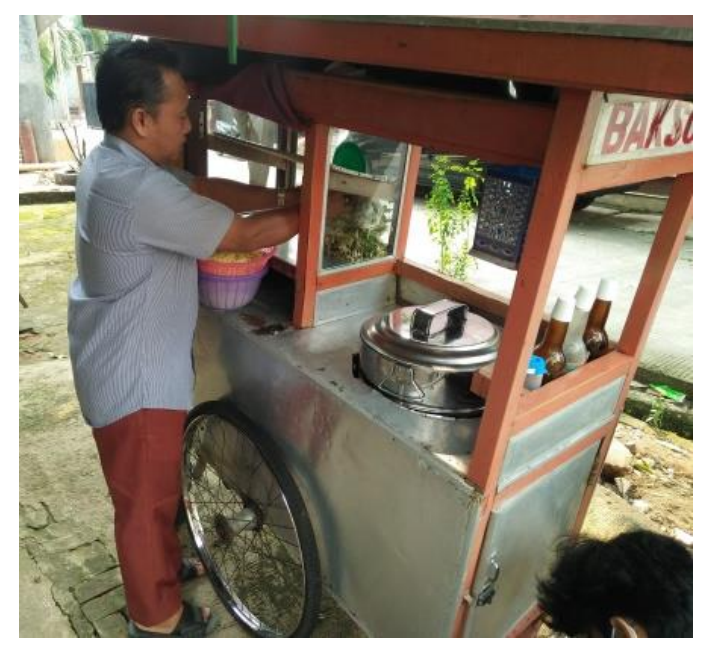

Gambar 4. Penjual tidak menggunakan masker. 


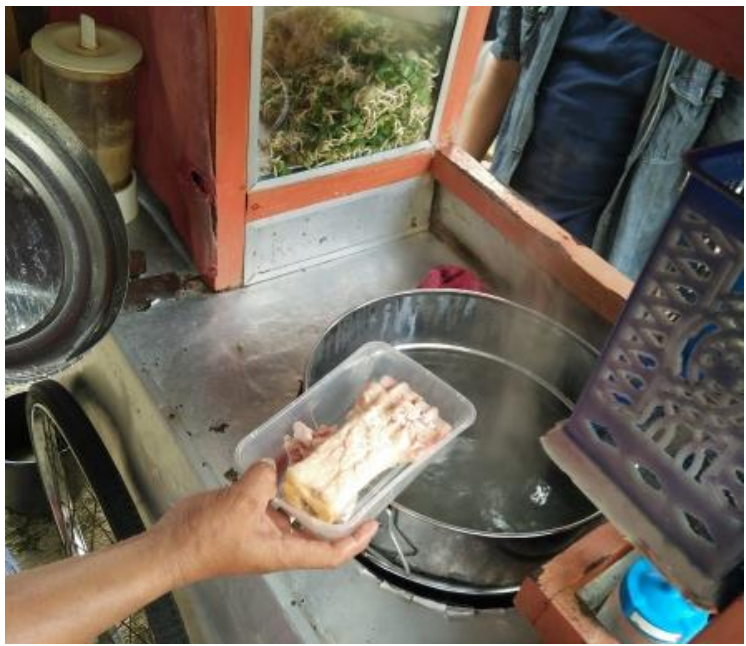

Gambar 5. Penjual tidak menggunakan sarung tangan.

Secara umum, pedagang keliling tersebut masih belum sepenuhnya patuh dan mengikuti protokol pencegahan penularan Covid-19 dan tidak menggunakan APD yang memadai selama proses berjualan berlangsung. Pedangan tidak menggunaan masker atau sarung tangan untuk melindungi diri dari terpapar Covid-9 (Gambar 4 dan 5).

Dari hasil observasi aktifitas berjualan yang dilakukan oleh pedagang bakso disekitar komplek perumahan, terjadi perubahan pola berjualan yaitu waktu mangkal lebih lama dari berjualan secara keliling, untuk jam operasional berjualan tidak mengalami perubahan dari sebelum masa pandemi. Rata-rata durasi waktu berjualan setiap hari sekitar 5 jam, dimana 3 jam lebih banyak untuk mangkal dan 2 jam untuk berjualan keliling komplek perumahan.

Observasi pola interaksi jual beli antara pedagang dan pembeli secara umum tidak ada perubahan kebiasaan. Pedagang dan pembeli masih belum menerapkan jarak aman untuk berinteraksi selama proses pemesanan dan pengambilan makanan, menunggu makanan, mengambil dan membayar makanan.

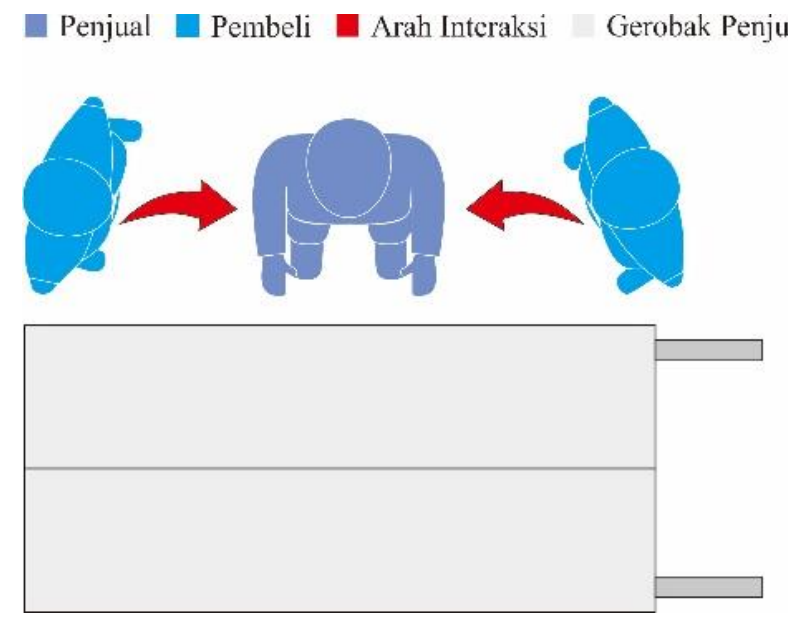

Gambar 6. Flow interaksi saat pembeli melakukan pemesanan makanan.

Dari hasil observasi tersebut memperlihatkan bahwa, pembeli lebih cenderung untuk melakukan kontak secara langsung dengan jarak dekat kepada penjual keliling, kontak secara langsung terjadi saat pembeli melakukan proses pemesanan makanan (Gambar 6), Umumnya antara pembeli dan penjual tidak memperhatikan jarak aman pada saat melakukan aktivitas tersebut, pembeli lebih merasa nyaman untuk medekati area penyimpanan makanan (a) dan penyajian makanan (b).

Kontak secara langsung antara pembeli dan penjual akan berkurang pada saat pembeli menunggu makanan yang akan disajikan oleh penjual. Pembeli umumnya cenderung untuk menunggu di sisi samping dan dibagian depan gerobak. Pada saat pembeli berada di area menunggu pada bagian sisi atau bagian depan gerobak, terdapat jarak yang cukup aman dari interaksi secara langsung antara penjual dan pembeli tersebut (Gambar 7).

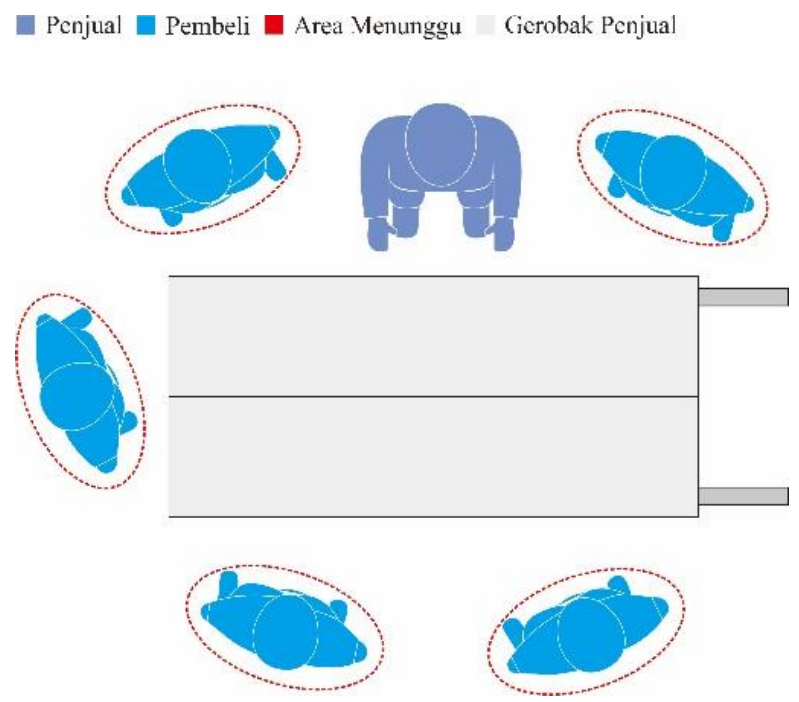

Gambar 7. Area pembeli menunggu makanan.
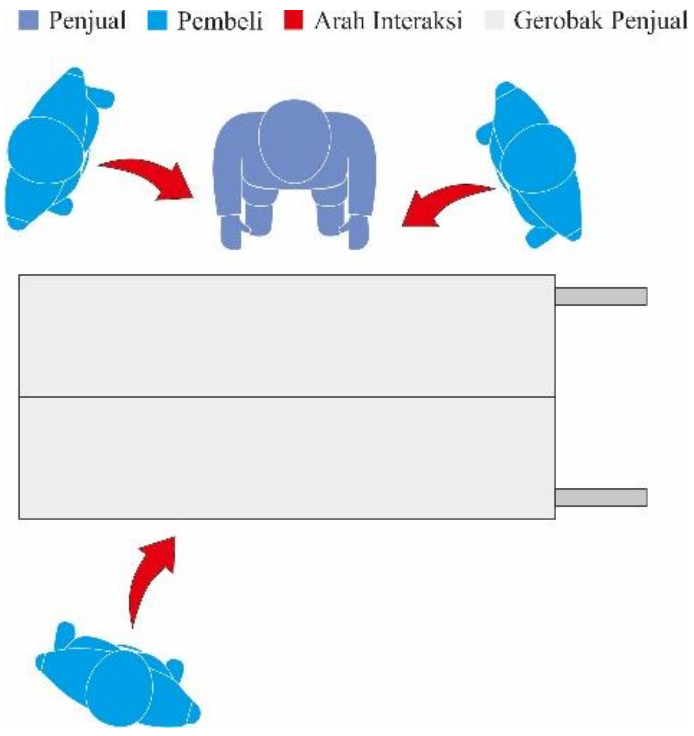

Gambar 8. Flow interaksi saat mengambil makanan.

Untuk proses pengambilan makanan, umumnya pembeli cenderung untuk mengambil dan mendekat ke area penyajian makanan (b) dan berada diposisi samping dari penjual bakso keliling tersebut. Terjadi peningkatan interaksi secara langsung dimana pembeli dan penjual berada pada jarak yang berdekatan. Untuk beberapa kasus, ada beberapa pembeli 
yang mengambil dari arah depan gerobak bakso (Gambar 8). Untuk proses transaksi pembayaran rata-rata dilakukan pada saat pembeli mengambil makanan, transaksi dilakukan dengan cara pembayaran uang tunai.

Selama masa pandemi, terjadi perubahan cara mengkonsumsi makanan yang dibeli dari penjual keliling tersebut. Dari hasil observasi yang dilakukan dilokasi komplek perumahan tempat penjual keliling tersebut berjualan, tidak ditemukan pembeli yang mengkonsumsi makanan yang telah dibeli disekitar gerobak tersebut. Pembeli rata-rata cenderung memilih untuk membawa pulang makanan dan dikemas menggunakan kemasan plastik. Untuk pembeli yang tempat tinggalnya berdekatan dengan lokasi mangkal penjual bakso keliling, rata-rata memilih untuk membawa alat makan sendiri.

Ada kesadaran bahwa menggunakan alat makan milik sendiri lebih terjamin untuk kebersihannya. Perubahan pola konsumsi ini menyebabkan perlengkapan cuci yang biasanya pada kondisi sebelum terjadinya pandemi digunakan untuk membersihkan peralatan makan yang digunakan oleh pembeli saat mengkonsumsi makanan dilokasi berjualan atau sekitar gerobak bakso tidak lagi digunakan, perlengkapan cuci tersebut lebih banyak digunakan untuk mencuci tangan penjual dan membersihkan area sekitar tempat penyajian makanan.

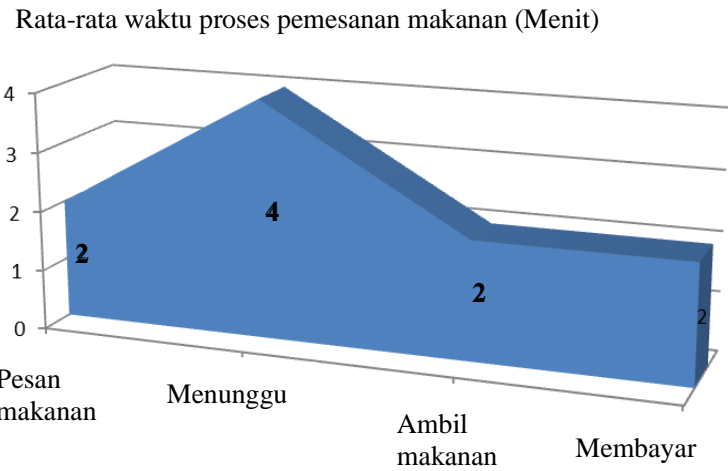

Gambar 9. Rata-rata waktu untuk menyelesaikan pemesanan makanan

Dari hasil analisa waktu yang diperlukan untuk proses transaksi antara penjual bakso keliling dan pembeli yang meliputi waktu untuk melakukan pemesanan makanan secara langsung kepada penjual bakso, waktu tunggu proses pembuatan dan penyajian makanan, waktu untuk proses mengambil makanan dan melakukan transaski pembayaran dapat dilihat pada Gambar 9. Rata-rata waktu yang diperlukan untuk menyelesaikan satu pesanan makanan dan disajikan ke pembeli memerlukan sekitar 4 menit. Proses menyerahkan makanan dan menyelesaikan pembayaran memerlukan waktu kurang lebih 4 menit.

Hasil analisa dari jarak interaksi antara penjual dan pembeli (Gambar 10) memperlihatkan jarak rata-rata untuk proses menunggu makanan antara pembeli dan penjual berjarak kurang lebih $100 \mathrm{~cm}$, apabila kedua pihak yang berinteraksi menggunakan APD seperti masker, jarak tersebut masuk dalam kategori jarak minimal yang aman dan sesuai dengan protokol pencegahan Covid-19 [14]. Jarak interaksi yang rawan dan tidak sesuai dengan protokol kesehatan yaitu pada saat proses pemesanan makanan, mengambil makanan dan melakukan transaski pembayaran

Rata-rata jarak antara individu $(\mathrm{cm})$

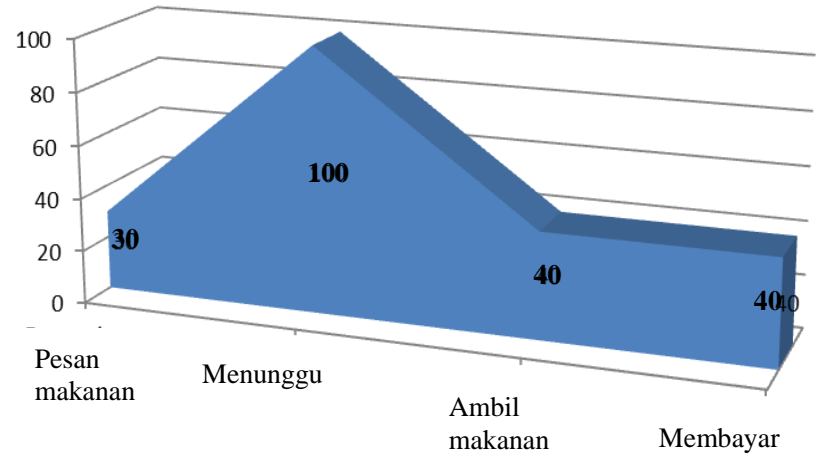

Gambar 10. Rata-rata jarak interaksi antara penjual dan pembeli berdasarkan proses aktivitas interaksi antara penjual dan pembeli.

secara tunai dimana antara penjual dan pembeli berjarak kurang lebih $30 \mathrm{~cm}$ sampai $40 \mathrm{~cm}$.

Dari hasil data tersebut dapat disimpulkan bahwa desain gerobak penjual bakso keliling harus memiliki fitur atau sistem agar dapat melindungi penjual dan pembeli dari terpapar Covid-19 saat keduanya berinteraksi untuk melakukan proses pemesanan dan pengambilan makanan serta melakukan proses pembayaran dengan jarak interaksi yang tidak aman yaitu kurang dari $100 \mathrm{~cm}$.

Selain itu, karena untuk mencegah penyebaran Covid-19, tingkat kebersihan dan higienitas dari seluruh fasilitas dan perangkat berjualan pedagang keliling harus diutamakan, material utama dari geobak yang digunakan oleh pedagang tersebut sebagian besar dibuat dari kayu dan logam seng, material tersebut dapat diganti dengan jenis yang mudah untuk dibersihkan, tahan korosi, higienis dan food grade, terutama untuk pada bagian area penyimpanan makanan dan penyajian makanan serta alat atau perlengkapan yang berkaitan dengan proses pengolahan makanan.

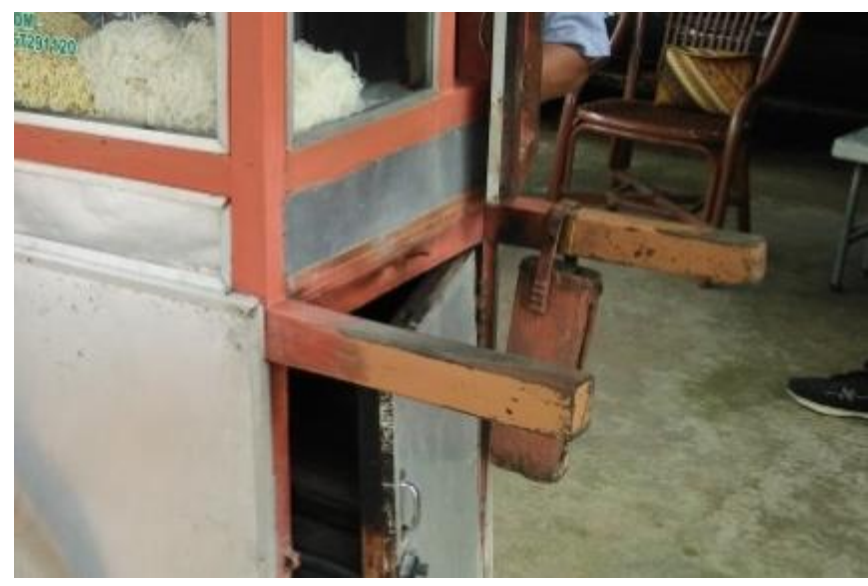

Gambar 11. Handle dorong gerobak bakso.

Material yang direkomendasikan untuk digunakan pada gerobak penjual bakso tersebut yaitu menggunakan bahan aluminium untuk struktur rangka utama gerobak, sedangkan untuk area yang berhubungan dengan penyimpanan makanan, memasak dan proses penyajian menggunakan material baja tahan karat seperti stainless steel. Logam stainless steel tipe AISI 304 [15] adalah jenis yang paling 
umum digunakan sebagai material dasar untuk peralatan atau perlengkapan yang berkaitan langsung dengan makanan atau pengolahan makanan. Material stainless steel 304 memiliki ketahanan korosi yang lebih baik dibanding dengan material jenis lain [16].

Selain aspek yang berkaitan dengan penyesuaian desain gerobak terhadap protokol kesehatan dan pencegahan penyebaran Covid-19, perbaikan dari desain gerobak ini ditinjau juga dari aspek ergonomi yaitu difokuskan kepada perbaikan desain handle dorong yang digunakan untuk mendorong gerobak pada saat penjual bakso tersebut berkeliling atau berpindah dari satu lokasi ke lokasi yang lain. Handle dorong yang saat ini terdapat digerobak tersebut dibuat dari material balok kayu ukuran $5 \mathrm{~cm}$ X $6 \mathrm{~cm}$ dengan panjang handle sekitar 40cm (Gambar 11).

Perbaikan yang dilakukan untuk desain handle dorong tersebut yaitu berdasarkan referensi Normalized Handle Size [17] dengan minimum diameter handle yang ditetapkan yaitu $3,3 \mathrm{~cm}$ dengan panjang $36 \mathrm{~cm}$. Desain handle pada bagian area grip di buat dengan kemiringan $5^{\circ}[18]$ untuk menambah daya dorong dan mempermudah pada saat gerobak tersebut didorong.

Berdasar analisa pada Tabel 3 dan hasil observasi lapangan serta analisa ergonomi untuk handle dorong gerobak bakso pada saat penjual tersebut melakukan proses aktivitas berjualan disekitar komplek perumahan, selanjutnya ditetapkan 10 spesifikasi final sebagai acuan untuk melakukan perbaikan pada desain gerobak penjual bakso keliling (Tabel 4).

Berdasarkan situasi new normal dan kondisi penyebaran Covid-19 yang masih membahayakan dan belum menunjukkan tanda pemulihan menuju kondisi yang lebih baik, konsep dari desain final gerobak penjual bakso keliling ini, diarahkan untuk digunakan dengan sistem berjualan mangkal atau menetap disuatu lokasi tertentu disekitar komplek perumahan dan mengurangi prekuensi untuk melakukan berjualan secara keliling.

Tabel 4. Spesifikasi final desain gerobak pedagang bakso keliling.

\begin{tabular}{|c|c|}
\hline No. & Redesain Gerobak \\
\hline 1 & $\begin{array}{l}\text { Terdapat pembatas pada bagian samping kiri dan kanan gerobak } \\
\text { yang berfungsi untuk melindungi pembeli dan penjual saat } \\
\text { melakukan proses pemesanan makanan }\end{array}$ \\
\hline 2 & $\begin{array}{l}\text { Terdapat canopy atau penutup atas untuk melindungi penjual } \\
\text { dari sinar matahari }\end{array}$ \\
\hline 3 & $\begin{array}{l}\text { Pengambilan makanan dan proses transaksi pembayaran } \\
\text { dilakukan pada bagian depan gerobak bakso }\end{array}$ \\
\hline 4 & $\begin{array}{l}\text { Terdapat area untuk meletakkan makanan yang siap diambil } \\
\text { oleh pembeli }\end{array}$ \\
\hline 5 & Sistem take way order dengan kemasan sekali pakai \\
\hline 6 & $\begin{array}{l}\text { Dilengkapi dengan disinfektan cair pada bagian depan gerobak } \\
\text { yang dapat digunakan oleh pembeli pada saat mengambil atau } \\
\text { melakukan pembayaran }\end{array}$ \\
\hline 7 & $\begin{array}{l}\text { Perbaikan pada desain handle dorong dengan mengikuti prinsip } \\
\text { ergonomic }\end{array}$ \\
\hline 8 & $\begin{array}{l}\text { Penggunaan material stainless steel food grade untuk area } \\
\text { penyajian makanan }\end{array}$ \\
\hline 9 & $\begin{array}{l}\text { Menggunakan material kaca untuk alas area tempat } \\
\text { penyimpanan makanan }\end{array}$ \\
\hline 10 & $\begin{array}{l}\text { Perbaikan desain untuk atap gerobak agar sirkulasi udara panas } \\
\text { dapat keluar secara normal }\end{array}$ \\
\hline
\end{tabular}
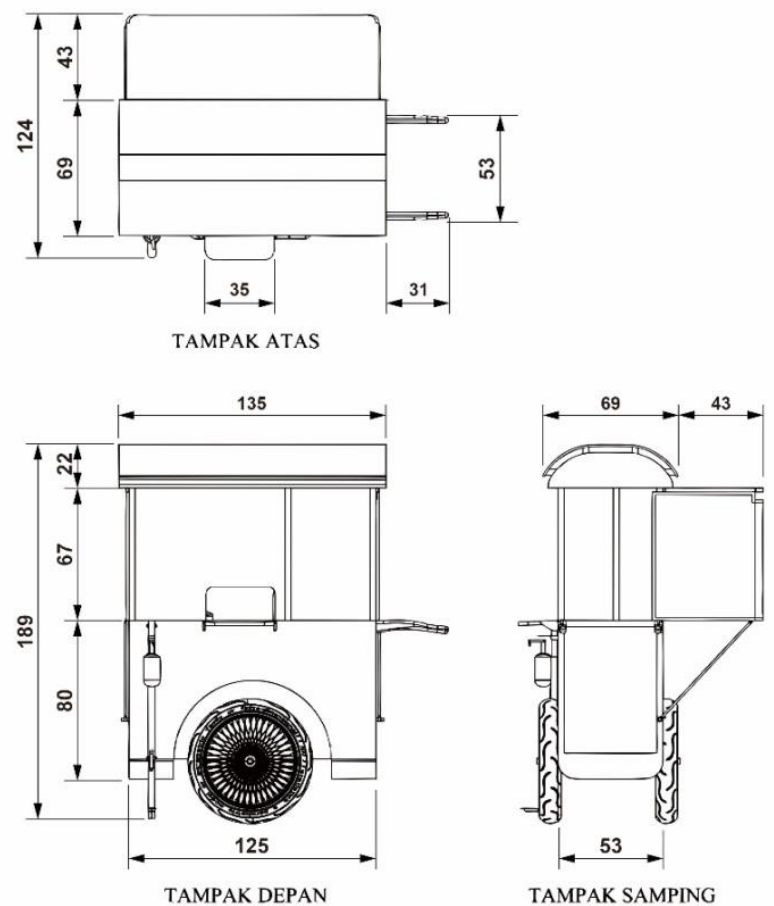

Gambar 12. Gambar tampak dan dimensi desain gerobak bakso (unit dalam $\mathrm{cm})$.

Desain sekat pembatas yang terdapat pada bagian samping kiri dan kanan pada desain gerobak tersebut akan efektif berfungsi untuk melindungi penjual dan pembeli dengan sistem berjualan yang menetap dilokasi tertentu.

Secara umum, dimensi keseluruhan dari desain gerobak tidak mengalami perubahan dari gerobak yang sebelumnya digunakan oleh pedagang bakso keliling tersebut. Perbaikan desain dilakukan dengan penambahan fitur dan perbaikan bentuk desain gerobak agar dapat memenuhi standar protokol kesehatan yang ditetapkan untuk kondisi new normal Covid19.

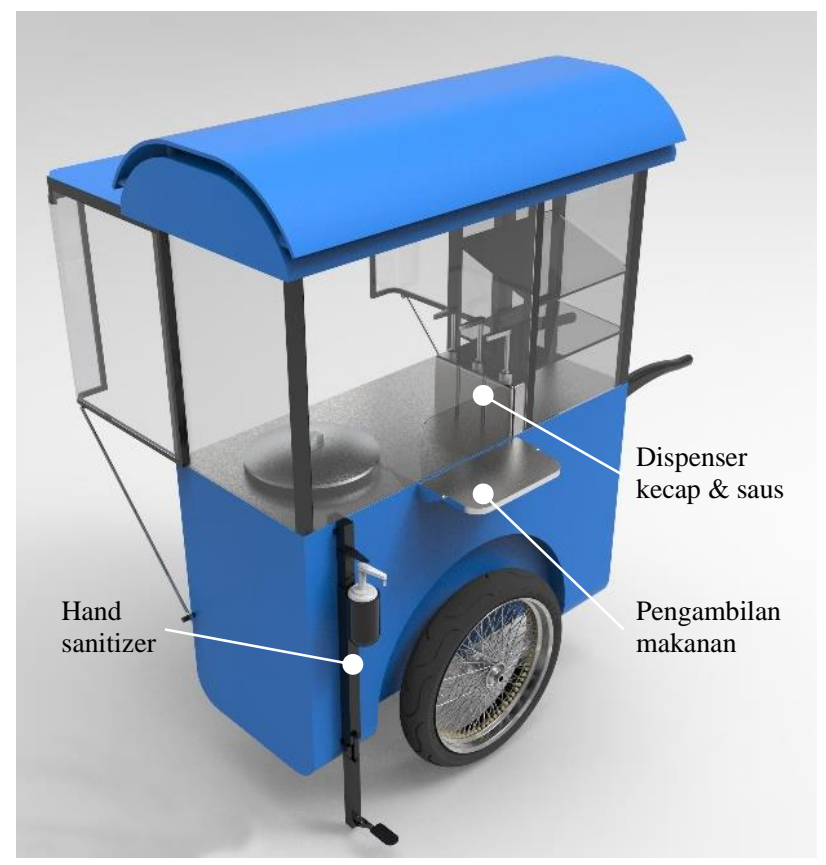

Gambar 13. Gambar 3D desain gerobak bakso pada saat berjualan. 


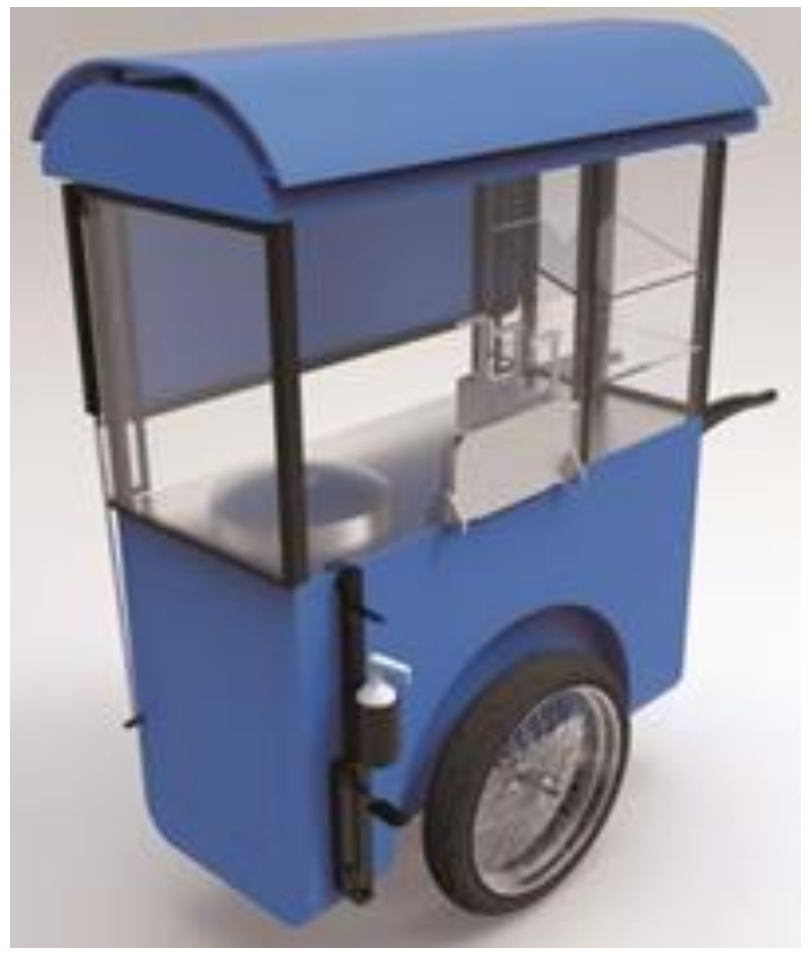

Gambar 14. Gambar 3D desain gerobak bakso pada saat tidak berjualan (a).

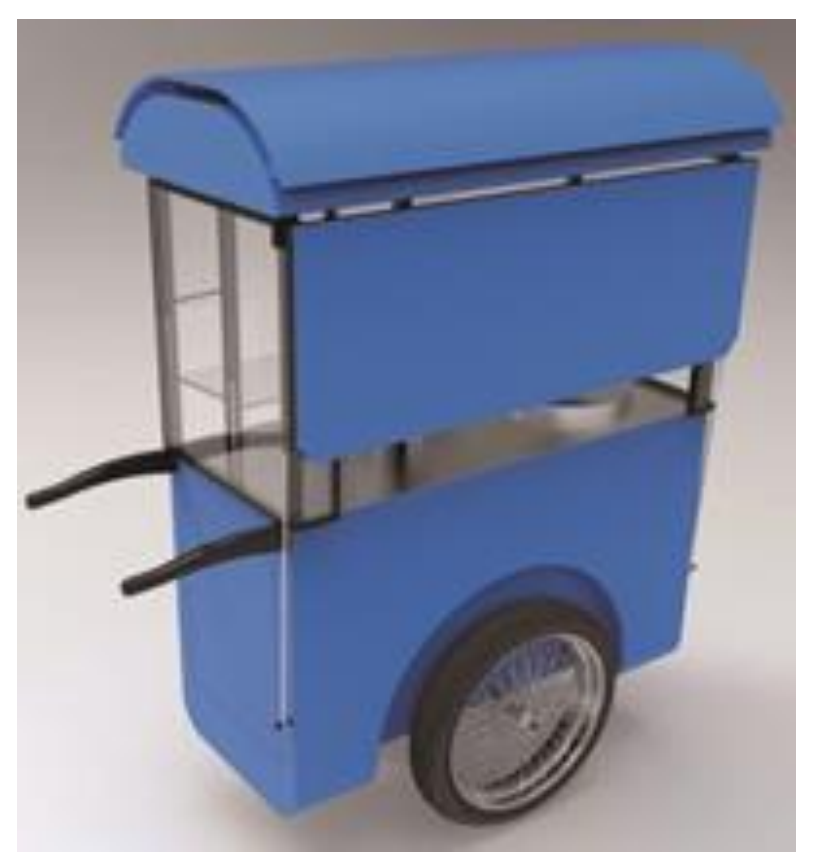

Gambar 15. Gambar 3D desain gerobak bakso pada saat tidak berjualan (b).

Dari hasil spesifikasi final tersebut, selanjutnya diterjemahkan kedalam pembuatan gambar kerja (Gambar 12) dan visualisasi desain gerobak $3 \mathrm{D}$ menggunakan software Solidworks (Gambar-gambar 13, 14 dan 15).

\section{KESIMPULAN/RINGKASAN}

Penelitian ini bertujuan untuk membantu pedagang bakso keliling agar gerobak dan sarana penunjang berjualan dapat sesuai dengan kondisi new normal pandemi Covid-19 dimana aspek penerapan protokol kesehatan harus dilaksanakan secara konsisten. Dari hasil observasi dan analisa data, selanjutnya dirumuskan spesifikasi yang harus dipenuhi untuk membuat desain gerobak penjual bakso keliling agar sesuai dengan kondisi new normal tersebut. Hasil desain gerobak yaitu bentuk dan fitur pendukung untuk dapat membatasi, melindungi dan memberi jarak interaksi antara penjual dan pembeli, meminimalkan kontak fisik secara langsung, penyediaan diinfektan yang dapat digunakan oleh pembeli pada saat mengambil dan melakukan transaksi pembayaran serta menerapkan sistem take way order untuk pembelian makanan. Secara keseluruhan, desain akhir yang dihasilkan dapat efektif digunakan untuk mendukung sistem berjualan dengan cara menetap disuatu lokasi dan pedagang keliling tersebut harus melengkapi dan menggunakan APD seperti menggunakan masker dan sarung tangan pada saat melakukan proses berjualan.

Implementasi lapangan untuk merealisasikan hasil desain kedalam bentuk prototype akan mengalami hambatan dari aspek biaya produksi, dimana penambahan fitur, perubahan bentuk gerobak dan penggunaan material stainless steel akan menaikkan biaya produksi, dimana saat ini para pedagang keliling tersebut sedang mengalami penurunan penghasilan.

Secara umum, penerapan desain gerobak ini dapat membantu untuk melindungi pedagang keliling dari penularan pandemi Covid-19 dan membantu meningkatkan kepercayaan pelanggan untuk membeli makanan dari pedagang keliling tersebut, efek positif yang diharapkan yaitu dapat memulihkan pendapatan para pedagang keliling yang saat ini sedang mengalami penurunan.

Penelitian dapat dilanjutkan untuk merealisasikan desain kedalam bentuk prototype gerobak sehingga manfaat dan efektifitas dari desain yang telah dibuat dapat diukur dan dianalisa sesuai dengan kondisi nyata dilapangan.

\section{DAFTAR PUSTAKA}

[1] C. CR Gan and F. Dwirahmadi, 'How Can The Public Be Better Protected Against Covid 19?', J. Berk. Epidemiol., vol. 8, no. 2, pp. 97-99, 2020, doi: 10.20473/jbe.v8i22020. 97-99.

[2] E. Tichelaar, 'Integrating Jakarta's street vendors in Architecture', Master Thesis Research, Technical University of Delft, Netherlands, 2015 .

[3] Sariffuddin, H. Wahyono, and Brotosunaryo, 'Street Vendors Hypergrowth: Consequence of Uncontrolled Urbanization In Semarang City', Int. J. Indones. Soc. Cult., vol. 9, no. 1, pp. 81-91, 2017, doi: 10.15294/komunitas.v9i1.8497.

[4] Muhyiddin, 'Covid-19, New Normal dan Perencanaan Pembangunan di Indonesia', Indones. J. Dev. Plan., vol. IV, no. 2, pp. 240-252, Jun. 2020, doi: 10.36574/jpp.v4i2.120.

[5] M. Nilzam Aly et al., 'Panduan Aman "New Normal" Menghadapi Pandemi Covid-19', J. Layanan Masy. J. Public Serv., vol. 4, no. 2 pp. 415-422, 2020, doi: 10.20473/jlm.v4i2.2020.415-422.

[6] O. Pratama, 'Pembinaan Kader Kesehatan dalam Upaya Peningkatan Kesehatan Lansia di Era Pandemi Covid', Bina Sehat Masy., vol. 1, no. 1, pp. 19-23, Apr. 2021.

[7] S. Anchal, 'Street Vending in Times of Covid-19 Guidelines For Street Vendors'. WIEGO, Nov. 2020. [Online]. Available: https://www.wiego.org/sites/default/files/publications/file/Street-

Vending-in-times-of-COVID-19-\%28English\%29.pdf

[8] 'Best Practices for Retail Food Stores, Restaurants, and Food Pick Up/Delivery Services During the Covid-19 Pandemic'. U.S. Food \& Drug Administration, Apr. 2020. Accessed: Jul. 08, 2020. [Online]. Available: https://www.fda.gov/

[9] T. Yansen, Y. Thedy, C. Theresia, and J. Octavia, 'Analisis Risiko Produk Alat Pelindung Diri (APD) Pencegah Penularan Covid-19 
untuk Pekerja Informal di Indonesia', J. Rekayasa Sist. Ind., vol. 9, no. 2, pp. 115-134, Jul. 2020, doi: 10.26593/jrsi.v9i2.4002.115-134.

[10] A. Mandasari, E. Harison, D. Sari, and N. Taufik, 'Adaptation Of Msmes Business In New Normal Conditions With The Implementation Of Standard Health Protocols', Pasundan Int. Community Serv. J. PICS-J, vol. 3, no. 1, pp. 14-21, Jun. 2021

[11] T. Rudyanta, 'Fenomena Penggunaan E-Wallet di Kalangan Pengusaha Warung Makan di Perkantoran Jakarta', J. Pewarta Indones., vol. 2, no. 1, pp. 41-48, Apr. 2020, doi 10.25008/jpi.v2i1.27.

[12] B. Smit, 'Observations in Qualitative Inquiry: When What You See Is Not What You See', Int. J. Qual. Methods, vol. 17, pp. 1-3, 2018, doi: $10.1177 / 1609406918816766$.

[13] S. abir, 'Methods of Data Collection', in Basic Guidelines for Research: An Introductory Approach for All Disciplines, Book Zone Publication, 2016, pp. 201-275. [Online]. Available: https://www.researchgate.net/publication/325846997_methods_of_d ata_collection
[14] 'Protokol Kesehatan Bagi Masyarakat Di Tempat Dan Fasilitas Umum Dalam Rangka Pencegahan Dan Pengendalian Corona Virus Disease 2019 (Covid-19)'. Menteri Kesehatan Republik Indonesia, Jun. 19, 2020.

[15] D. AK, P. AD, and B. AG, 'Stainless Steel for Dairy and Food Industry: A Review', J. Mater. Sci. Eng., vol. 4, no. 5, pp. 1-4, 2015 doi: 10.4172/2169-0022.1000191.

[16] Sumarji, 'Studi Perbandingan Ketahanan Korosi Stainless Steel Tipe Ss 304 Dan Ss 201 Menggunakan Metode U-Bend Test Secara Siklik Dengan Variasi Suhu dan Ph', J. ROTOR, vol. 4, no. 1, pp. 1-8, Jan. 2011

[17] A. Bhatia, P. Kalra, and J. Singh, 'Ergonomic Design of Trowe Handle', Int. Res. J. Eng. Technol., vol. 3, no. 7, pp. 819-824, Jul. 2016.

[18] J. Kaljun and B. Dolšak, 'Ergonomic Design Recommendations Based on An Actual Chainsaw Design', South Afr. J. Ind. Eng., vol. 23, no. 2, pp. 215-229, Jul. 2012. 